\title{
Spending blood for oil in Nigeria: a frame analysis of Shell's neutralisation of acts that led to corporate-initiated state crime
}

\author{
Enes Al Weswasi, Research assistant at the Department of \\ Criminology, Stockholm University ${ }^{l}$
}

\begin{abstract}
The environmental impact of Shell Oil Company in Nigeria has resulted in largescale protests. Despite their peaceful nature, these protests have been met with lethal violence by the Nigerian security forces. Accusations have been levelled against Shell for liability for human rights violations, but the company has denied responsibility. Previously confidential correspondence between Shell and Nigerian officials has shown that the company repeatedly persuaded security personnel to act against protesters. The current article examines how Shell framed its desire for the Nigerian state to suppress protests against the company. It does this by analysing published documents within Stanley Cohen's (1993) theoretical framework regarding the neutralisation of criminal acts - most notably the neutralisation technique of appealing to higher loyalties. This is a technique adopted by companies when they use the greater good as a rationale for minimising their responsibility for harmful acts. The correspondence between Shell and Nigerian officials shows that Shell continuously urged Nigerian officials to take action by referring to the company's contribution to economic and social development in the region, even after their calls for action has been shown to result in human rights abuses. In describing these rationales, the article highlights a case of corporate-initiated state crime, a form of crime that involves corporations inducing state actors to commit harmful acts.
\end{abstract}

1. The work with this article has been conducted within the context of the project "Business as usual. Corporate strategies in response to allegations of crime", financed by Riksbankens Jubileumsfond (RJ P15-0176:1). I would like to thank Sandra Egelström, Janne Flyghed, Gustav Grut, Evelina Jansson, and Isabel Schoultz for all the helpful discussions and comments. I would also like to thank the two anonymous reviewers for their comments and David Shannon for his valuable comments and proofreading. 


\begin{abstract}
Oljebolaget Shells miljöpåverkan i Nigeria har resulterat i storskaliga protester från lokalbefolkningen. Trots dess fredliga karaktär har protesterna bemötts med våld från nigerianska säkerhetsstyrkor vilket resulterat $i$ hundratals döda. Anklagelser har återkommande riktats mot Shell för delaktighet i kränkningar av mänskliga rättigheter $i$ samband med händelserna, något som Shell tagit avstånd från. Offentliggörandet av tidigare okända dokument, innehållande interna anteckningar och korrespondens mellan Shell och nigerianska tjänstemän, visar hur företaget uppmanat nigerianska säkerhetsstyrkor att agera mot protestdeltagarna. I denna artikel kommer de publicerade dokumenten att analyseras med syftet att utröna hur Shell valt att rama in de uppmaningar som framställts till den nigerianska staten. Uppmaningarna kommer att vidare förstås med hjälp av Stanley Cohens (1993) neutraliseringstekniker, i synnerhet tekniken 'vädjan till högre lojalitet' vilken appliceras av företag för att minimera deras ansvar för brottsliga eller skadliga handlingar. Analysen av dokumenten visar att Shell återkommande manat nigerianska säkerhetsstyrkor att bemöta protesterna med motiveringen att Shells fortsatta bidrag till ekonomisk och social utveckling $i$ regionen annars ej kan fortskrida. Neutraliseringarna föranleder vad som kan kallas för 'företagsinitierat statsbrott', $i$ vilken företag förmår stater att begå skadliga gärningar.
\end{abstract}

\title{
Introduction
}

Shell Oil Company's involvement in violence and controversies in Ogoniland, in south-east Nigeria, during the 1990s has been a topic of recurrent discussion in the literature on state-corporate crime (Manby 1999; Boele et al. 2001a; Tombs $\&$ Whyte 2015). However, Shell has continually distanced itself from the allegations and from the acts carried out by the Nigerian state and there have been difficulties in establishing what legal role Shell has played in the unfolding events (Manby 1999; Amnesty International 2017a). From a criminological perspective, it is critical to understand the techniques adopted by corporations when distancing themselves from harmful acts because doing so shows how companies rationalise their own actions and how they perceive criminal liability. The rationales expressed by companies also provide a basis for further elaboration of the theoretical understanding of state-corporate crime and the symbiosis that may exist between business entities and state actors in relation to acts of deviance.

The conflict in Ogoniland has emanated from activities associated with the extraction of oil in the region, against which there have been continuous protests by local communities, which claim that Shell is devastating and plundering the region of its natural resources, without providing compensation for the damage 
the company is doing. Furthermore, Nigerian security forces have repeatedly targeted the protests with repression, with this repression escalating during the 1990s into fatal violence culminating in the deaths of hundreds of people. Human rights organisations have repeatedly accused Shell of having criminal liability for these events, and since the 1990s the company has been the object of three lawsuits relating to complicity in human rights abuses against the Ogoni people (see Ako 2015; Pegg 2015; CCR 2018; CCR 2019).

In 1996, the first lawsuit (Wiwa v. Shell) was brought in New York by relatives of the murdered individuals known as the Ogoni Nine, a group of nine activists from Ogoniland who were hanged in 1995 in a criminal case that has been described as extrajudicial by human rights organisations (Amnesty International $2017 \mathrm{~b}$ ). On the eve of the trial, in June 2009, the case was settled without going to trial. The plaintiffs received a total of $\$ 15.5$ million, but Shell made it clear, in settling the case, that they did not accept any liability for human rights violations. The second legal case against Shell (Kiobel v. Shell) was dismissed by the US Supreme Court in 2013, due to jurisdictional issues, with the court holding that the case did not "touch and concern" the US with "sufficient force".

A third and ongoing ${ }^{2}$ civil law case was initiated in 2017 in the Netherlands. The lawsuit once again concerns Shell's complicity in the executions of the Ogoni Nine and has been brought by a group comprising four widows of the men who were hanged. The widows' legal team has been supported during the trial by Amnesty International, and in November 2017 the organisation released a batch of previously unpublished documents that could possibly confirm Shell's culpability. The documents include correspondence between Nigerian officials and Shell representatives.

This article utilises these published documents in examining how Shell specified and imposed its will for the Nigerian state to suppress the protests against Shell's presence in Ogoniland via communications with Nigerian officials and military personnel. The documents will be processed by means of a frame analysis focusing on how Shell has framed the predicaments it faced as a result of the protesters' opposition against Shell's operations. The company's arguments will further be understood on the basis of Cohen's (1993) theoretical concepts regarding the neutralisation of one's own culpability in deviant acts, and most notably the neutralisation technique of suggesting that particular acts are less damaging due to their serving to promote a greater good (appealing to higher loyalties). The

2. As of September 2019, the lawsuit has not yet been settled. 
research question this article aims to answer is: How did Shell rationalise its calls for action when persuading Nigerian state officials and Nigerian security forces to act against the protests of the Ogoni people. Concepts and ideas from the literature on state-corporate crime will be incorporated with the intention of pinpointing the continued close relationship between the Nigerian state apparatus and Shell, and potentially highlighting the company's legal responsibility in relation to the atrocities that have occurred in Nigeria since the 1990s.

\section{Background: Shell's Search for Oil in Nigeria and the Crisis in Ogoniland}

In 1958, Shell discovered its first commercial oil field in Nigeria and the region has since become, in the company's own words, "Shell's largest and most complex exploration and production venture" outside North America (quoted in Boele, Fabig, and Wheeler 2001a, 75). Shell has grown to become the largest gas company in the region, accounting for about 50 per cent of all crude oil production, in a region in which oil accounts for more than 90 per cent of the country's foreign exchange and more than 80 per cent of federal government revenue (Soremekun and Obi 1993; Kretzman 1995).

The petroleum industry in Nigeria changed dramatically in the 1970s, when large parts of the production process were nationalised. The nationalisation was partly precipitated by Nigeria's desire to join the Organization of the Petroleum Exporting Countries (OPEC), which encouraged member states to acquire at least a 51 per cent share of their national petroleum industry. Following negotiations with the Nigerian state, Shell Oil in Nigeria became a Nigerian subsidiary and the Dutch holding company consequently transferred 55 per cent of its shares to the Nigerian government. The process of nationalisation established an increasingly intimate relationship between the transnational oil industry and the Nigerian state, which now had an even larger incentive in relation to national oil production (Obi 1997).

By the 1980s, resistance against the Nigerian government had begun to develop in the region of Ogoniland among community members who argued that the state was marginalising the Ogoni people both politically and economically (Boele, Fabig, and Wheeler 2001a). In parallel with this, Shell came to be heavily criticised by the Ogoni people as a result of increasing pollution and soil devastation, which was destroying agriculture and other sources of revenue. The resistance became formalised in August 1990, when the Movement for the Survival of the Ogoni People (MOSOP) was established by Ken Saro-Wiwa. MOSOP experienced its first lethal encounter with the authorities just three months after its initiation when the Nigerian Mobile Police (MOPOL), a paramilitary force, attacked 
and killed twelve protesters in Umuechem, east of Port Harcourt in Rivers State (Manby 1999). Over the following days, residents gathered to protest the killings, only to be met by additional lethal force at the hands of MOPOL, this time resulting in the killings of 80 protesters in what became the Umuechem massacre.

The above events pacified tensions in the region, as large parts of the country went into shock at what had happened. However, the tranquillity had lasted less than two years when MOPOL, in July 1992, once again used lethal force against protesters who had gathered to oppose Shell's oil extraction activities, resulting in eleven wounded and one protestor being fatally shot. MOSOP and other human rights organisations responded to the attacks made by MOPOL by declaring a national Ogoni day, on January $3^{\text {rd }}$, 1992, on which date 300,000 peaceful demonstrators gathered to declare Shell 'persona non-grata' in Ogoniland (Boele et al. 2001a; Amnesty International 2017a). A couple of days later, Shell announced that it would halt all its operations indefinitely in the region due to difficulties ensuring the security of employees working in its production facilities. Violence in the region continued, however, throughout 1993 and the following year, including lethal attacks against demonstrators who had sporadically gathered outside Shell installations to protest against the environmental damage being done by Shell's remaining oil extraction activities. Moreover, the Ogoni people were subject to large-scale attacks, resulting in hundreds of deaths, in actions that were described by local news agencies as 'ethnic clashes' between the Ogoni people and residents from nearby regions. However, the Ogonis viewed these lethal attacks on them as retribution for their involvement in protests against Shell and the Nigerian state (Osaghae 1995; Boele et al. 2001a). The Nigerian government did subsequently try to mediate a peace treaty in the region that was supposed to halt the violence, but Ken Saro-Wiwa and other leading figures of the MOSOP opposed the treaty. They argued that the treaty could be interpreted as legitimizing a resumption of Shell's operations in Ogoniland due to a paragraph that described an "immediate resumption of all full economic and social activities" (Boele 1995:22). In 1995, the human rights organization Unrepresented Nations and Peoples Organization (UNPO) published a leaked memorandum from the Nigerian government. Under the title Restoration of Law and Order in Ogoniland, the document did indeed describe the reestablishment of Shell operations but also encouraged violence to quash the leaders of the Ogoni protest movement. "Shell operations still impossible unless ruthless military operations are undertaken for smooth economic activities to commence. [...] Wasting targets cutting across communities and leadership cadres especially vocal individuals" (Boele 1995, 39). In Nigeria, the published document confirmed in part the previous accusati- 
ons; attacks against the Ogoni people were in fact politically motivated and initiated by the government.

The decision by Ken Saro-Wiwa and others to refuse the peace treaty resulted in a split within the MOSOP organization linked to different views regarding how the organization should proceed tactically (Amnesty International 2017c; Boele 1995). In the middle of 1994, the crisis in Ogoniland came to a head when a meeting initiated by a faction of MOSOP (which was critical of the leadership of Ken Saro-Wiwa and his unwillingness to cooperate with the government) was attacked, resulting in the deaths of four leading figures within the organization. Shortly afterwards, the police went public with claims that nine individuals (who would later become the Ogoni Nine) had been apprehended for the murders - amongst them Ken Saro-Wiwa. The nine accused men were subsequently hanged after their case was heard by a tribunal that was criticised by human rights organizations for being extrajudicial (Boele 1995; Manby 1999; Amnesty International 1995, 2017c). Amnesty International denounced the trial shortly before the executions: "The prosecutions appear to be politically motivated and the proceedings and decisions of the special tribunal set up specifically to try the cases do not satisfy international standards for fair trial" (Amnesty International 1995, 1). During the trial, the accused men told the tribunal that they were being tortured and forced to confess their alleged crimes and were also being coerced into identifying the other indicted men as perpetrators (Amnesty International 1995).

\section{The Symbiosis between Shell and the Nigerian State}

The concept of state-corporate symbiosis, introduced by O'Reilly (2010), provides a basis for strengthening our understanding of Shell's culpability in the events that have unfolded in Nigeria. The two actors in the current context - Shell and the Nigerian state - are not two separate entities but have instead become merged in the pursuit of continued prospecting and petroleum extraction activities in Nigeria. "In general terms, a symbiotic relationship suggests an ongoing close association between two organisms where the outcome for one is strongly connected with that of the other" (O'Reilly 2010, 197). Conceptually, a state-corporate symbiosis directs an emphasis at underlying economic and political processes, beyond mere events (Tombs 2012). The fact that most of Shell Oil's Nigerian shares were owned by the Nigerian state illustrates the way in which a symbiosis can emerge from an economic process.

The symbiosis between the entities also became political when Shell gained control over various policy decisions in Nigeria. In 2010, Wikileaks published a series of leaked telegrams containing correspondence between Shell executives 
and US embassies, including documents relating to Shell in Nigeria (The Guardian 2010). In one such telegram, Ann Pickard, then Shell's vice-president for subSaharan Africa, boasted about having actively deployed Shell employees across all vital departments in Nigeria, which had resulted in Shell being able to directly influence Nigeria's decision-makers. This could be interpreted as a form of revolving door by means of which individuals from one party move to the other party (O'Reilly 2010) albeit without the knowledge of the Nigerian state. Residents in Ogoniland have repeatedly expressed that they have felt excluded from the democratic process and that policy decisions have not been made in order to promote the region but rather strictly to benefit corporate interests, and what appears in the Wikileaks documents thus reinforces the claims that the Ogoni people have been making for a long time.

\section{Techniques of Neutralisation of Past and Future Delinquency}

In their article Techniques of neutralization, Sykes and Matza (1957) propose a theory that explains various discursive techniques implemented by juveniles in order to neutralise or rationalise criminal acts. The theory contends that individuals are not principally committed to values associated with deviance but rather adhere to conventional attitudes and beliefs. The authors describe how juvenile offenders rationalise and neutralise their own actions, which are otherwise viewed as deviant, and in doing so avoid a sense of guilt or perceived stigmatisation. One such technique - appeal to higher loyalties - describes how deviant acts can be justified by offenders on the basis of a rationalisation that the action was committed for the benefit a social group (e.g. circle of friends, family, etc.) to which the individual in question belongs. In addition, rationalisations are not limited to past acts but also constitute a means of justifying forthcoming actions that might benefit the individual's social group (see Maruna and Copes 2005).

Since the inception of the theory of neutralisation techniques, the various techniques have been further refined by several scholars in order to better understand how rationalisations are adapted to function in aggregated contexts, such as organizations, companies or states (Rothe and Kauzlarich 2016). Stanley Cohen (1993) has expanded the theory of techniques of neutralisation along these lines by pinpointing the ways in which states apply neutralisations to their actions when trying to avoid public guilt or repercussions. In a state context, the previously described technique, the appeal to higher loyalties, might be understood as a means of rationalising questionable acts by claiming that they benefit the nation, its people or the country's economic well-being. This article will apply Cohen's revised theoretical framework of neutralisations, and the appeal to 
higher loyalties technique in particular, in its processing of the selected documents. The technique will mainly be used to develop an understanding of how Shell persuaded the Nigerian state to take actions against the Ogoni people in Nigeria.

The theory of neutralisation techniques has been used in numerous studies focused on analyses of corporate denial in various business sectors. One study of the ways in which large industrial emitters of greenhouse gases defend themselves in public interviews has revealed that the neutralisation techniques employed often refer to either self-proclaimed excellence in the relevant field (thus distancing themselves from poor practices used by competitors) or to claims of making contributions to economic and social development; a third alternative involved the organisations in question neutralising their acts by denying or minimising them (Talbot and Boiral 2015). In a paper examining the automobile industry's response to major car safety scandals, Whyte (2016) has argued that corporations purposely try to tap into and shape 'common sense' among the public when defending themselves. Business entities try to distance themselves from allegations of deviance via claims that corporate deviance is not 'real crime' or by emphasising that specific operations are socially beneficial (i.e. by creating jobs or providing investment in communities). These types of justifications, based on 'quasiphilanthropic' rationales of wealth creation, developing peace and democracy along with the overall contributions to society, are also found in large-scale western transnational corporations that operate in financially impoverished or repressive countries (Schoultz and Flyghed 2016).

Concerning corporations' use of neutralisation techniques, Huisman (2010) has argued that appeals to higher loyalties are predominantly centred around employment (e.g. securing employee safety) or economic interests (e.g. securing investment or producing economic and/or democratic development in the host country) and are used to reduce culpability for rule violations.

\section{Frame Analysis and the Published Documents}

The documents analysed in this article consist of internal memorandums, meeting notes and correspondence, and have been compiled by Amnesty International through various court proceedings. ${ }^{3}$ Some of the documents have been available for some time, but Amnesty International received additional documents in April

3. Individual documents are available via Amnesty International's website https://amnesty.app. box.com/s/kixmsmvi8601oaux3eff80w8wbifbq15 [2019-06-26] 
2017 when the organisation filed a British Freedom of Information request, which enabled the release of documents containing additional correspondence made in the 1990s, between Shell staff and Nigerian officials (Amnesty International 2017a). Amnesty International published parts of these documents in November 2017 in connection with the lawsuit filed by the four widows of the Ogoni Nine (Amnesty International 2017c). Each quote from the published documents presented below has been given an identical identification as in the source material ("exhibit 20", "exhibit 11", etc.), allowing the reader to re-examine the documents in their extended versions. Of the 53 published documents in total, less than a dozen include calls for action, with half of these including neutralisations and thus being of relevance for this article.

The analytic method of frame analysis has been used to process the documents with the intention of highlighting various ways in which Shell has adapted the appeal to higher loyalties neutralisation technique. Frame analysis has its origins in Ervin Goffman's (1974) essay Frame analysis but has later been developed to be applicable to a broader range of contexts. Methodologically, it is in part comprised of a content analysis, but has the purpose of searching for and identifying underlying meanings in miscellaneous framings of explicit problems (Koenig 2006). When problems are described in certain ways, these descriptions also imply both causes and suggested solutions (Schön \& Rein 1994). It is the discursive capacity to transfer power from words into action that makes frame analysis a suitable tool for interpreting and understanding the power of expressed language. Frame analysis has previously been used in studying how Shell in Nigeria was framed in the public discourse during the crucial year of 1995 (Holzer 2007).

The analysis process was broken down into two steps. In the first, documents were examined and broadly coded with regard to instances where Shell urged either security forces or state officials to take action in relation to the Ogonis' protests against Shell's activities. This step utilised frame analysis by highlighting the language used in framing issues relating to the protests and the company's calls for action against them. This then connects to the second step, in which Shell's rationales, in calling for action, were examined with the aim of identifying justifications that could be classified as appeals to higher loyalties. Narrow codes have been employed which were intended to capture various rationales expressed by Shell. The intent in this second step has been to scrutinise how Shell has appealed to loyalties other than the pure vested interest of the company when describing both the origins of the problems and why the Nigerian state should consider Shell's appeals. 


\section{Results: A Claim for Shell's Complicity in Harmful Acts in Nigeria}

The people of Ogoni and their organized resistance against Shell and for the preservation of the region commenced on August $26^{\text {th }}, 1990$, via the formation of the Movement for the Survival of the Ogoni People (MOSOP) (Amnesty International 2017a; Boele et al. 2001a). Shell became early aware of the high level of local support for this protest movement in Ogoniland, and the risks this might involve for the company. Shell's staff sent a letter to the Nigerian Police Office just two months after the launch of MOSOP, in which Shell elected to frame the problem of MOSOP's protests and the solution to these in a dramatic way, in order to elicit a response in line with Shell's wishes.

We write to inform you of an impending attack proposed for early hours of tomorrow 30/10/90 by members of Umuechem Community [...]. The cause of this threat cannot be immediately ascertained but it is not unlikely to be connected with demand for social amenities [...]. In anticipation of the above threat, we request that you urgently provide us with security protection (preferably Mobile Police Force) at this location. [...]. We trust you will give us the desired cooperation on this matter to enable us to have a peaceful and safe operating environment necessary to achieve our planned crude oil production targets (29/10/1990 - Exhibit 20).

The above letter is dated two days before twelve protestors were shot and killed by the Nigerian paramilitary force in what subsequently became known as the Umuechem Massacre, at the outset of the long-lasting crisis in Ogoniland. In their letter, Shell expressed a belief that a lack of response to the residents' protests would involve a threat to Shell economically, and the company urged the Nigerian police to stop the protests. In the literature discussing the cooperation between corporations and states in criminal and other harmful acts (state-corporate crime) a distinction is made between acts initiated by the state (state-initiated crime) and acts of avoidance by states which choose not to stop or provide protection against harmful acts committed against their citizens (state-facilitated crime) (Kramer et al. 2002; Kauzlarich, Mullins \& Matthews 2003; Tombs \& Whyte 2015). However, in the case of the above letter, the actions fall between the conceptual cracks in this regard, since while the acts were committed by the Nigerian state, the interference was requested by Shell. In order to capture these kinds of actions, Lasslett (2010) introduced a supplementary concept - corporate-initiated state crime - which better pinpoints the situation examined here. Corporate-initiated state crime is defined as acts that occur when corporations directly employ their economic power to coerce states to commit deviant acts. Corporate-initiated state crime thus emphasizes the power dynamic that is exploited by corporations in or- 
der to convince states to engage in harmful acts that benefit the corporation in question.

Shell's operation falls within the framework of corporate-initiated state crime since Shell called for action from the state, and exploited the company's economic power to achieve its will. This imbalance of power between Shell and the local population becomes clearer in the succeeding correspondence. The earlier framing of the problem and the desired solution is further elaborated in the following letter, which was addressed to the governor of the region, by including a reference to the economic well-being of the nation, which again demonstrates how Shell has employed economic rationales both to justify its own operations and to persuade the Nigerian state to act against the protesters.

We feel very worried about these stoppages and their resultant impact on our ability to meet the Nation's production target. [...] We therefore humbly solicit Your Excellency's intervention to enable us to carry out our operations given the strategic nature of our business to the economy of this nation (19/03/1993 - Exhibit 12).

The higher loyalty of profit maximisation plays a pivotal role in the way that corporations and states rationalise misconduct within the framework of statecorporate crime and is an essential element that needs to be recognised when identifying the symbiosis between Shell and the Nigerian state. Shell reiterates its framing of the problem-solution throughout its correspondence with Nigerian officials, members of the military and civil servants, as being a matter of the protestors constituting an obvious problem for Shell and its operations in Ogoniland, and furthermore for the Nigerian state. The company argues that objections to Shell's presence threaten the economic well-being of Nigeria and the solution to this threat is for the Nigerian state to counteract the Ogoni protests so that the state does not lose any additional economic revenue that Shell has the potential to generate. The higher loyalty referred to in the neutralisation technique employed by Shell - appeal to higher loyalties - consists in this context of the economic well-being of the state. Cohen (1993) describes how the nation is a recurring focus of loyalty adopted when criminal and other harmful acts are being rationalised. In another case, references to economic growth were likewise used as a neutralisation technique when a Swedish oil company had to answer accusations relating to harmful prospecting and oil extraction in Sudan (Schoultz \& Flyghed 2016). It shows how easy it is for companies to assign economic interests a driving force in order to continue the extraction of other countries' natural assets. 
With time, the problem framing maintained by Shell was developed, from containing vague data on production losses to including clearer figures with the intention of pressuring the Nigerian state, by highlighting economic concerns, to act against individuals who were protesting against Shell's presence. The following correspondence was once again addressed to the governor of the region and is akin to the previous correspondence, but it adds information on the exact damage that has been done by protesters to the company's total revenue. It should be noted that the letter is dated 1993, by which time several years of lethal repression by the Nigerian state had been well documented. Shell was thus aware of the methods used by the Nigerian state to curb the protests against Shell's presence.

Presently, we achieve only $50 \%$ of our planned work target and have incurred very high downtime cost due to the continued disruption of operations. [...] Having made several unsuccessful attempts to resolve the problem, we felt constrained to bring the above situation to your notice and solicit your usual assistance in helping us to resolve the issues to enable our operation to continue undisturbed (07/01/1993 - Exhibit 11).

In a later letter, addressed to among others Nigeria's military leadership, Shell described production losses to further reinforce the impact that the protesters are claimed to have had on the company's operations, and calls for action to minimise future production disruptions. In doing so, Shell thus used its financial power to initiate acts, which the company must have been aware had often resulted in gross human rights violations by the Nigerian state.

It is alarming to note that the cumulative crude oil shut-in resulting from community disruptions from January 1993 to $13^{\text {th }}$ December 1993 is 8,988,660 barrels. We would therefore appreciate any assistance you can give to minimize these disruptions (16/12/1993 - Exhibit H).

The production losses described above might, however, rather be the consequence of Shell's own actions and not necessarily the result of the protests of local residents. As was described in the historical background, Shell decided in January 1993 to pull out of the region of Ogoniland after being declared persona non-grata by the Ogoni people. The company's withdrawal from the region, and thus the self-inflicted downsizing of production was undoubtedly party responsible for the crude oil shut-in that Shell in the above letter attempted to pin on the Ogonis' protests. Shell maintained, nonetheless, its appeal to economic motives that were mutually beneficial to both Shell and the Nigerian state. 


\section{Conclusion}

Using a frame analysis and Cohen's (1993) understanding of the neutralisation technique appeal to higher loyalties, this case study has been able to show how Shell has used profit-maximising claims - the economic well-being of the state as a recurring framing. The rationale employed by Shell has been effective in convincing the Nigerian state to suppress Nigerians who chose to protest Shell's destructive presence. The use of such references has also been described in previous studies that have analysed how corporations have rationalised harmful activities (Huisman 2010; Talbot and Boiral 2015; Whyte 2016; Schoultz and Flyghed 2016). However, the current study on the case of Shell in Nigeria differs from those described in the previous research, since the use of the neutralisation technique was adopted by Shell to rationalise demands for action, rather than to neutralise past acts, which was often the case in the examples described in the existing literature. This thus highlights the need for an expansion of the conventional framework of the neutralisation techniques employed by corporations which could further develop our understanding of how corporations neutralise acts - regardless of whether this neutralisation occurs prior to or after the commission of the acts in question.

Huisman (2010) has stated that neutralisations are predominantly after-thefact statements and are seldom encountered before an event occurs. Rationalisations could, Huisman argues, nonetheless reveal and play an intrinsic part in the motives for pursuing a specific coercive objective in the first place. The results of this study, which relate to articulated neutralisations of anticipated actions, strengthens this argument that neutralisations are not isolated after-the-fact rationalisations but rather an indication of a normalisation of situations in which the actor might be interpreted as being culpably involved, in Shell's case in human rights violations.

To further define the intimate relationship between Shell and the Nigerian state, concepts linked to state-corporate crime have been incorporated. Due to Shell's instigating role in the events that have unfolded in Nigeria, the company's actions have been described as a case of corporate-initiated state crime (Leslett 2010), which distinguishes it from most of the cases described in the traditional literature on state-corporate crime (Kramer et al. 2002; Kauzlarich, Mullins \& Matthews 2003; Tombs \& Whyte 2015). This is an important insight since it can help to expand the question of legal responsibility so as to include not only those who have had their fingers on the trigger but also those who encourage and benefit from the acts. For years, Shell has distanced itself from the abuse to which Ogoni's has been subjected by the Nigerian state. However, the documents 
examined in this study have shown that Shell has used its economic power to impose its will. Thus, Shell's use of the neutralisation technique of appealing to higher loyalties has directly contributed to harmful acts in Ogoniland.

Nevertheless, the legal issue is difficult to approach. It is unlikely that the $\mathrm{Ni}$ gerian state would bring Shell to justice for complicity, in part because the state has itself benefited from Shell's presence, but most importantly because the state has ultimately been the actor committing the abuse. The ongoing civil law case against Shell, filed by the widows of four of the Ogoni Nine, is being resolved by a court in the Netherlands, the country from which Shell Nigeria's parent company operates (The Guardian 2017). A partial victory for the widows was won in the case in May 2019, when a Dutch court ruled that it has jurisdiction to hear the damages suit brought against the company (The Guardian 2019). The ruling also stipulated that Shell must hand over confidential internal documents regarding the issue of Shell's conduct in Ogoniland, more specifically, any documents concerning the company paying people to provide false information about the Ogoni Nine to Nigerian law-enforcement officials.

In addition to Shell's alleged complicity and involvement in the violations in Ogoniland, their operations has also had a devastating environmental impact in Nigeria, to an extent that will be almost impossible to repair (Obi 1999; Boele, Fabig, and Wheeler 2001; Sinden 2008; Izarali 2016). In January 2015, a London high court held Shell liable for its oil spills in the Niger Delta (see Pegg \& Zabbey 2013; Fentiman \& Zabbey 2015) but there is good reason to further analyse how Shell has unrestrainedly contributed to the destruction of both the environment and human life. In the same way as the human rights issue, the issue of the company's environmental impact raises a range of questions with regard to statecorporate crime as a result of the unwillingness or inability of the Nigerian state to protect its citizens (state-facilitated crime) from Shell's adverse activities.

Following Amnesty International's publication of the documents described above, Shell decided to comment on the statements made by Amnesty International and the claims made by the widows of the Ogoni Nine. Shell's comment comes roughly thirty years after the events in Ogoniland commenced, but the way the company has chosen to frame the events and their rationalisations are strikingly similar to the framings found in earlier documents.

In the past and today, Shell Companies in Nigeria have made many contributions to the Nigerian economy, not only through the energy they produce and revenues and employment they generate for the country but also via their extensive supply chain, local content and social investment (cited in Amnesty International 2017a, 87). 
In the letter addressed to Amnesty International, Shell denies collusion with the Nigerian military and responsibility for the cruelties committed against the Ogoni people. Shell concludes the letter by appealing to the same higher loyalty that the company has repeatedly appealed to in the past.

Throughout this article, the neutralisation techniques adopted are described as arguments made by Shell, but the techniques are in fact expressed by individual representatives. This is not to downplay Shell's responsibility for the events in Ogoniland and pin the blame on individuals. Instead, individuals' neutralisations could rather be viewed as signs of potential cultures of cynical attitudes within corporations that are internalised and expressed through individual employees in order to appease the company and their goal of economic growth.

Economic development is an obvious, powerful greater good which is desired by many, but as this article has shown, it can also lead to gross human rights violations. Thus, criminology and the conceptual framework of state-corporate crime has a critical role to play in identifying and highlighting the processes by which economic resources can be used to coerce states into committing illicit acts.

\section{References}

Ako, R. (2015). A Lega (1) Cy Unfulfilled: Reflections of the Wiwa-Led MOSOP and the Localisation of Human Rights. The Extractive Industries and Society 2 (4): 625-34.

Amnesty international. (1995). Nigeria - The Ogoni Trials and Detentions.

Amnesty international. (2017a). A criminal enterprise? London.

Amnesty International. (2017b). "Nigeria: Shell Complicit in the Arbitrary Executions of Ogoni Nine as Writ Served in Dutch Court." https:/www.amnesty.org/en/latest/news/2017/06/ shell-complicit-arbitrary-executions-ogoni-nine-writ-dutch-court/. [Accessed 2018-02-9]

Amnesty international. (2017c). In the Dock: Shell's Complicity in the Arbitrary Execution of the Ogoni Nine. London.

Boele, R. (1995). Ogoni: report of the UNPO mission to investigate the situation of the Ogoni of Nigeria, February 17-26, 1995. Unrepresented Nations and Peoples Organization.

Boele, R., Fabig, H., \& Wheeler, D. (2001a). Shell, Nigeria and the Ogoni. A study in unsustainable development: I. The story of Shell, Nigeria and the Ogoni people-environment, economy, relationships: conflict and prospects for resolution. Sustainable development, 9(2), 74-86.

Boele, R., Fabig, H., \& Wheeler, D. (2001b). Shell, Nigeria and the Ogoni. A study in unsustainable development: II. Corporate social responsibility and 'stakeholder management' versus a rights-based approach to sustainable development. Sustainable Development, 9(3), 121135.

CCR. (2018). "Kiobel v. Royal Dutch Petroleum Co. (Amicus).” https://ccrjustice.org/home/ what-we-do/our-cases/kiobel-v-royal-dutch-petroleum-co-amicus [Accessed 2019-09-02]

CCR. (2019). "Wiwa et al. v. Royal Dutch Petroleum et al." https://ccrjustice.org/home/whatwe-do/our-cases/wiwa-et-al-v-royal-dutch-petroleum-et-al [Accessed 2019-09-02] 
Cohen, Stanley. (1993). "Human rights and crimes of the state: the culture of denial." Australian \& New Zealand Journal of Criminology 26 (2): 97-115.

Fentiman, A., \& Zabbey, N. (2015). Environmental degradation and cultural erosion in Ogoniland: a case study of the oil spills in Bodo. The Extractive Industries and Society, 2(4), 615-624.

Goffman, E. (1974). Frame analysis: An essay on the organization of experience. Cambridge, MA, US: Harvard University Press.

Huisman, W. (2010). Business as Usual? Corporate Involvement in International Crimes. Hague: Eleven International Publishing.

Holzer, B. (2007). 'Framing the Corporation: Royal Dutch/Shell and Human Rights Woes in Nigeria.' Journal of Consumer Policy 30 (3): 281-301.

Izarali, M.R. (2016). Human Rights and State-Corporate Crimes in the Practice of Gas Flaring in the Niger Delta, Nigeria. Critical Criminology, 24(3), 391-412.

Kauzlarich, D., Mullins, C., \& Matthews, R. (2003). A complicity continuum of state crime. Contemporary Justice Review, 6(3), 241-254.

Kretzman, S. (1995). Nigeria's' Drilling Fields. Multinational Monitor, January/February 8.

Koenig, T. (2006). Compounding Mixed-Methods Problems in Frame Analysis through Comparative Research. Qualitative Research 6 (1): 61-76.

Kramer, R.C., Michalowski, R.J., \& Kauzlarich, D. (2002). The origins and development of the concept and theory of state-corporate crime. Crime \& Delinquency, 48(2), 263-282.

Lasslett, K. (2010). “A Critical Introduction to State-Corporate Crime.” http://statecrime.org/ state-crime-research/state-corporate-crime-crit-intro/. [Accessed 2018-02-11]

Manby, B. (1999). The price of oil: corporate responsibility and human rights violations in Nigeria's oil producing communities. New York: Human Rights Watch.

Maruna, S., \& Copes, H. (2005). What have we learned from five decades of neutralization research? Crime and justice, 32, 221-320.

Obi, C.I. (1997). Globalisation and local resistance: The case of the Ogoni versus Shell. New Political Economy, 2(1), 137-148.

Obi, C.I. (1999). Globalization and environmental conflict in Africa. African Journal of Political Science/Revue Africaine de Science Politique, 4(1), 40-62.

O'Reilly, C. (2010). The Transnational Security Consultancy Industry: A Case of StateCorporate Symbiosis. Theoretical Criminology 14 (2): 183-210.

Osaghae, E.E. (1995). The Ogoni Uprising: Oil Politics, Minority Agitation and the Future of the Nigerian State. African Affairs 94 (376): 325-44.

Pegg, S. (2015). Introduction: On the $20^{\text {th }}$ Anniversary of the Death of Ken Saro-Wiwa. The Extractive Industries and Society 2 (4): 607-14.

Pegg, S., \& Zabbey, N. (2013). Oil and water: the Bodo spills and the destruction of traditional livelihood structures in the Niger Delta. Community Development Journal, 48(3), 391-405.

Rothe, D., \& Kauzlarich, D. (2016). Crimes of the powerful: An introduction. Routledge.

Schoultz, I., \& Flyghed, J. (2016). Doing business for a "higher loyalty"? How Swedish transnational corporations neutralise allegations of crime. Crime, Law and Social Change, 66(2), 183-198.

Schön, D.A., \& Martin R. (1994). Frame Reflection: Toward the Resolution of Intractable Policy Controversies. New York: BasicBooks. 
Sinden, A. (2008). An Emerging Human Right to Security from Climate Change: The Case against Gas Flaring in Nigeria. Adjudicating Climate Change: Sub-National, National, And Supra-National Approaches, William CG Burns, Hari M. Osofsky, Eds.

Sutherland, E.H. (1940). White-collar criminality. American sociological review 5 (1): 1-12.

Soremekun, K., \& Cyril O. (1993). The Changing Pattern of Private Foreign Investments in the Nigerian Oil Industry. Africa Development/Afrique et Développement, 5-20.

Sykes, G.M., \& David M. (1957). Techniques of neutralization: A theory of delinquency. American sociological review 22 (6): 664-70.

Talbot, D., \& Olivier B. (2015). Strategies for Climate Change and Impression Management: A Case Study among Canada's Large Industrial Emitters. Journal of Business Ethics 132 (2): 329-46.

The Guardian. (2010). "WikiLeaks Cables: Shell's Grip on Nigerian State Revealed." http://www.theguardian.com/business/2010/dec/08/wikileaks-cables-shell-nigeria-spying. [Accessed 2018-02-12]

The Guardian. (2017). "Ogoni Widows File Civil Writ Accusing Shell of Complicity in Nigeria Killings.” http://www.theguardian.com/global-development/2017/jun/29/ogoni-widows-filecivil-writ-accusing-shell-of-complicity-in-nigeria-killings. [Accessed 2018-02-13]

The Guardian. (2019). 'Dutch court will hear widows' case against Shell over deaths of Ogoni Nine." https://www.theguardian.com/global-development/2019/may/01/dutch-court-willhear-widows-case-against-shell-over-deaths-of-ogoni-nine-esther-kiobel-victoria-berahague. [Accessed 2019-06-28]

Tombs, S., \& David W. (2015). The corporate criminal: why corporations must be abolished. Key ideas in criminology. Abingdon, Oxon; New York, NY: Routledge, Taylor \& Francis Group.

Whyte, D. (2016). It's Common Sense, Stupid! Corporate Crime and Techniques of Neutralization in the Automobile Industry. Crime, Law and Social Change 66 (2): 165-81. 